\title{
Flood vulnerable zones in the rural blocks of Thiruvallur district, South India
}

\author{
Punitha Periyasamy ${ }^{1 *}$ (D) Mohamed Mohamed Yagoub $^{2}$ and Mahalingam Sudalaimuthu ${ }^{3}$
}

\begin{abstract}
Background: Flooding is not simply the flow of water from higher topography to lower topography. Rather, it is the interface dynamics between geo-terrain system parameters; viz., lithology, geological structures, geomorphology, soil, drainage conditions, slope, land use and land cover etc., and flood. Hence the flood vulnerability mapping requires the understanding and mapping of all terrain parameters. With this in mind, an attempt has been made to delineate flood vulnerable zones in the rural blocks of Thiruvallur District, Tamil Nadu, covering an area of $1557.07 \mathrm{Sq}$. Km that consists of 7 blocks from RK Pet to Thiruvallur fall in the study area.

Results: The thematic maps such as drainage, geology, geomorphology, landuse, and landcover, tectonic map with special reference to lineaments and detection of zones of land subsidence on the basis of drainage anomalies along them were prepared using Resourcesat-2 LISS IV - 2014 data. The collateral data includes rainfall for a period of 40 years collected from 1974 to 2014 from 5 rain-gauge stations collected and the Rainfall Isohyet Map was prepared. The digital elevation model (DEM) was generated using Shuttle Radar Topographic Mission (SRTM) and the slope of the study area was obtained. ArcGIS 10.3 acts as a powerful spatial analysis tool to find out the flood vulnerable zones in the study area by means of weighted overlay analysis. Each individual parameter of the thematic maps are ranked and weighted in accordance with their vulnerability to flood in the study area are classified; viz., highly vulnerable, moderately vulnerable, less vulnerable and no vulnerable with their aerial extent of 426.47, 181.57, 832.25 and 116.78 Sq.Km respectively. The GIS-based output result is then validated by obtaining the list of flood-affected villages in real time.

Conclusion: The multi-criteria analysis allowed the integration of several elements for mapping the flood vulnerable zones. Results revealed that about $40 \%$ of the study area is exposed to high and medium flood vulnerability. The structural and non-structural measures recommended in this research will help the decision makers and planners to effectively develop strategies for future flood occurrences within the rural blocks of the district.
\end{abstract}

Keywords: DEM, IRS p6, Flood, Lineament, Vulnerable zones

\section{Introduction}

Floods are the one of the natural hazards that affect India almost every year causing huge loss of lives and properties. The destruction from a tropical flood depends mainly on rainfall, its duration, intensity and location, soil type, geological condition, geomorphological feature, land use and landcover type. Flood kills thousands of people and destroy billon of rupees worth habitat and property. After floods has passed, devastation often continues which can cause not only

\footnotetext{
* Correspondence: punithaperiyasamy@gmail.com

${ }^{1}$ Department of Civil Engineering, SRM University, Kattankulathur, 603203

Kancheepuram, Tamil Nadu, India

Full list of author information is available at the end of the article
}

the spread of diseases, but transportation, communication and infrastructure may also be destroyed. The main causes of changes in flood risk are climatic changes, changes in land use and other anthropogenic activities such as urban growth, the partial or total cover of torrent banks, watercourse alignment, improperly dimensioned bridges, deforestation, consequent erosion, the construction of roads or other structures across the watercourse, subsidence observed in flat regions due to over-pumping, and the change or deviation of the watercourse (Green et al. 2000). The scale and frequency of floods are likely to increase due to climate change, which will bring higher intensity of rainfall and rising sea levels as well 
as to inappropriate river management and construction in flood plains which reduces their capacity to absorb flood waters. (Ajin et al. 2013).

Despite their devastating effects, floods are also beneficial as it wets the drought affected areas and recharges the dry aquifer. This kind of natural hazard cannot be avoided but can be managed successfully through proper flood management plan. The principal objective of this study was to analyse all possible resource maps to delineate the probable flood vulnerable zones. The present paper identifies the flood vulnerable zones by analysing the satellite imageries of the respective period and GIS enables the integration and management of multi thematic data. Thematic layers on drainage, slope, soil, geology, geomorphology, land use and landcover, lineament and zones of possible tectonic subsidence were prepared, and these layers were analysed by overlay analysis with 40 years northeast monsoon rainfall for generating possible flood vulnerable zonation map. Flood hazard maps can be used effectively as an evacuation manual during a flood occurrence and offers local residents with information on the flood danger levels of their properties (Noble et al. 2016).

\section{Study area}

Thiruvallur district is one of the major districts in Tamilnadu, covering an area of 1557.07 Sq.km. Out of 14 blocks, only rural blocks were chosen for the study as more than $70 \%$ of the people's livelihood depends on agriculture and related activities and this region is susceptible to both flood and drought disaster on account of its land use conditions. The rural region of the district covers 7 blocks namely RK Pet, Pallipattu, Tituttani, Thiruvalangadu, Poondi, Kadambathur, and Thiruvallur. The study area is bounded by Andera Pradesh in the north, Chennai district in the south, Poondi, Vellore district in the east and Bay of Bengal in the west. The study area is situated between the coordinates of E longitudes $79^{\circ} 17^{\prime} 34.8^{\prime \prime}$ and $80^{\circ} 2^{\prime}$ $34.8^{\prime \prime}$ and $\mathrm{N}$ latitudes $13^{\circ} 20^{\prime} 31.2^{\prime \prime}$ and $12^{\circ} 56^{\prime} 27.6^{\prime \prime}$ has total geographical aerial extent of 1557.07 Sq.Km (Fig 1).

\section{Objective}

The general objective of the study is to demarcate probable flood vulnerable zone using multi criteria evaluation technique. In connection with the above general objective the following specific objectives are outlined.

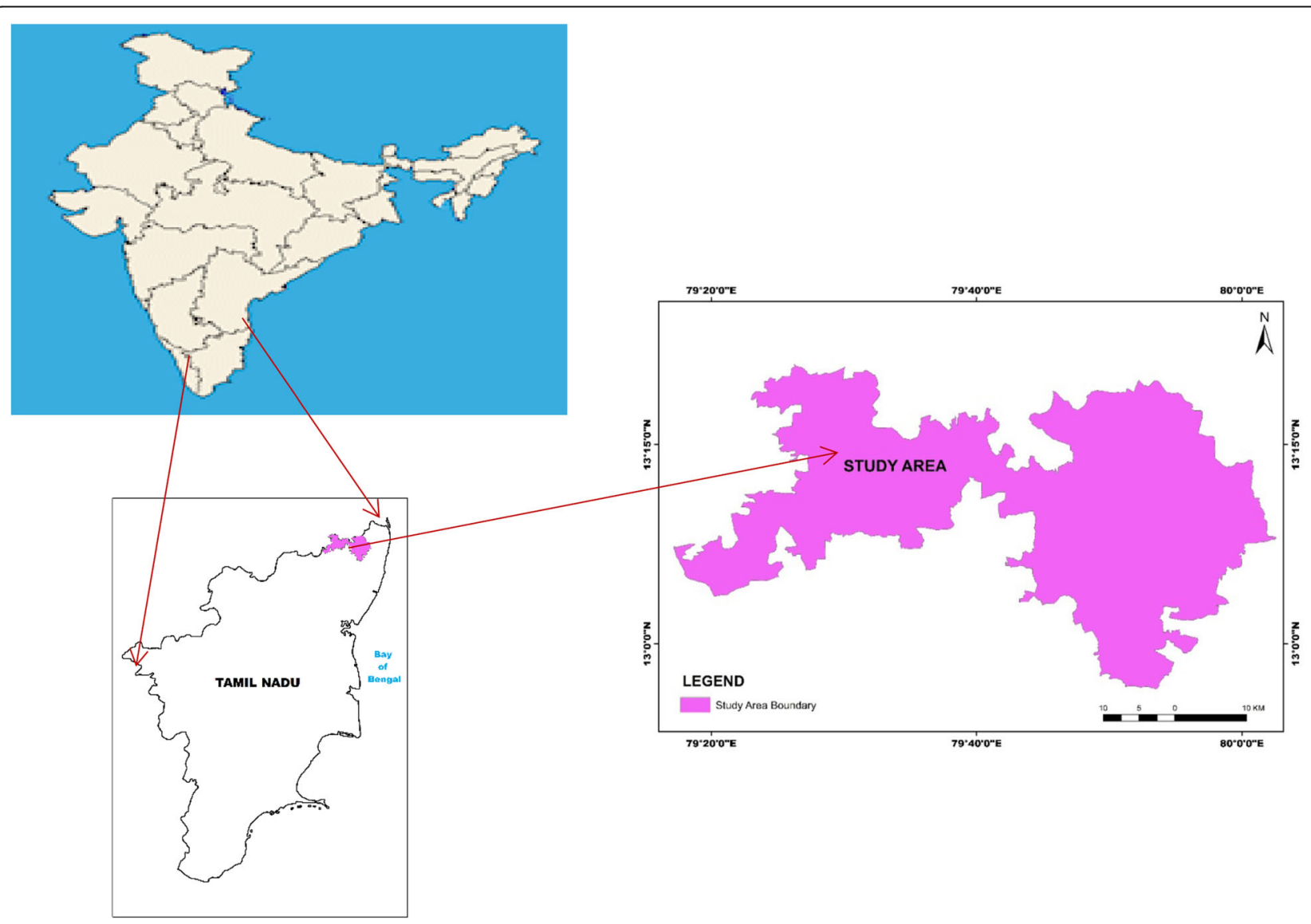

Fig. 1 Location map 
a. To identify the causative factors of flood in the study area.

b. To develop block-wise flood vulnerable zonation map using satellite data, historical data and collateral data.

c. To recommend structural and non-structural mitigation measures for the recurrent flood risks.

\section{Materials}

The methodology involves delineation of water bodies from Survey of India toposheets $57 / \mathrm{O} 7,8,11,12,15,16$, $57 / \mathrm{P} 13,66 / \mathrm{C} 4$ on $1: 50000$ scale. Resource maps such as drainage, land use and landcover, geomorphology, lineament and zones of subsidence have been derived from remote sensing satellite sensor Resourcesat-2 LISS IV MX, 2014 which provides a revisit period of 5 days and a spatial resolution of $5.8 \mathrm{~m}$. (NRSC 2011). It is used for mapping drainage, land use and landcover, geomorphology, lineament and zones of subsidence. Soil map had been received from the agriculture department of Tamil Nadu. The slope map was prepared from SRTM data in ArcGIS Spatial Analyst module. More than 50\% of the seasonal rainfall contribution is given by northeast (NE) monsoon. Hence, NE rainfall data from the year 1975 to 2015 were collected and used for analysis of hydro-system. Geology and structure of the study area is generated based on the published District Resources maps of Geological Survey of India.

\section{Causes of flood}

The periods of past floods and the details of respective affected villages from the year 1996 to 2014 have been collected and analysed from the existing database. The output reveals that the study area is flooded mainly due to two reasons. The main cause for flooding is due to an aftermath of meteorological events such as an intense and prolonged rainfall, increase in water level in coastal and estuarine waters due to storm surges and seiches as the study area is close to bay of bengal. The other reason is breaching of Kosasthalaiyar and Coovam rivers and a spate of Poondi Reservoir.

\section{Methodology}

The general methodology adopted for this study includes collection of spatial and non-spatial data. The spatial data are in the form of maps like drainage, elevation, slope, geology, geomorphology, land use and land cover, lineament, land subsidence and soil which are stored as different layers in digital form in the database. The rainfall data pertaining to attribute information is in the form of tables and list. Integration of spatial and non-spatial data, querying, analysis etc. are done in GIS environ. Thus, the new maps are generated precisely by easily integrating innumerable layers of data and manipulating to evaluate relationships among the chosen elements in different layers under consideration.

The overlay analysis includes combining data from multiple data categories and performing analytical, statistical measurement and other operations on the GIS data sets to transform the data into information suitable for a given application. Integration of various thematic maps can be done by overlaying one theme over the other progressively and by adopting suitable decision criteria. The typical operations include overlaying different thematic maps, computing areas and performing logical operation. Different themes interpreted from satellite and topographical data were

Table 1 Criteria for vulnerable map

\begin{tabular}{|c|c|c|c|c|}
\hline S.No & Map Layer & Phenomenon & Need & Source \\
\hline 1. & Rainfall & Rainfall - Runoff & Major cause of flooding & Ajin et al. 2013 \\
\hline 2. & Drainage Density & Structure of water holding & Major cause of flooding & Setiawan et al. 2017 \\
\hline 3. & Elevation & Ground surface Topography & Areas of susceptibility & Ouma and Tateishi 2014 \\
\hline 4. & Slope & Rainfall-Runoff-Erosion & Flood wave velocity & Sumedh et al. 2012 \\
\hline 5. & Geology & Geology & $\begin{array}{l}\text { Result of physical surface processes and } \\
\text { the lithology. }\end{array}$ & Cao et al. 2016 \\
\hline 6. & Geomorphology & $\begin{array}{l}\text { Physical processes on the earth's surface } \\
\text { that produce different landforms }\end{array}$ & $\begin{array}{l}\text { A geomorphic unit is a composite unit in } \\
\text { which each feature has specific } \\
\text { characteristics. }\end{array}$ & Mili and Acharjee 2014 \\
\hline 7. & Land use and landcover & $\begin{array}{l}\text { Purpose for which land has been } \\
\text { put } \\
\text { to use. }\end{array}$ & Indicates the state of current use. & Ajin et al. 2013 \\
\hline 8. & Lineaments \& Intersection & $\begin{array}{l}\text { Zones of structural weakness in } \\
\text { the rocks; }\end{array}$ & Geo Dynamics of flood; & Pareta 2012 \\
\hline 9. & Zones of Tectonic Subsidence. & $\begin{array}{l}\text { Easy movement of water along } \\
\text { weak planes. }\end{array}$ & Geo Dynamics of flood; & Setiawan et al. 2017 \\
\hline 10. & Soil & Infiltration - Runoff & $\begin{array}{l}\text { Efficiency of the soil to acts as a sponge } \\
\text { and soak up water }\end{array}$ & Danumah et al. 2016 \\
\hline
\end{tabular}




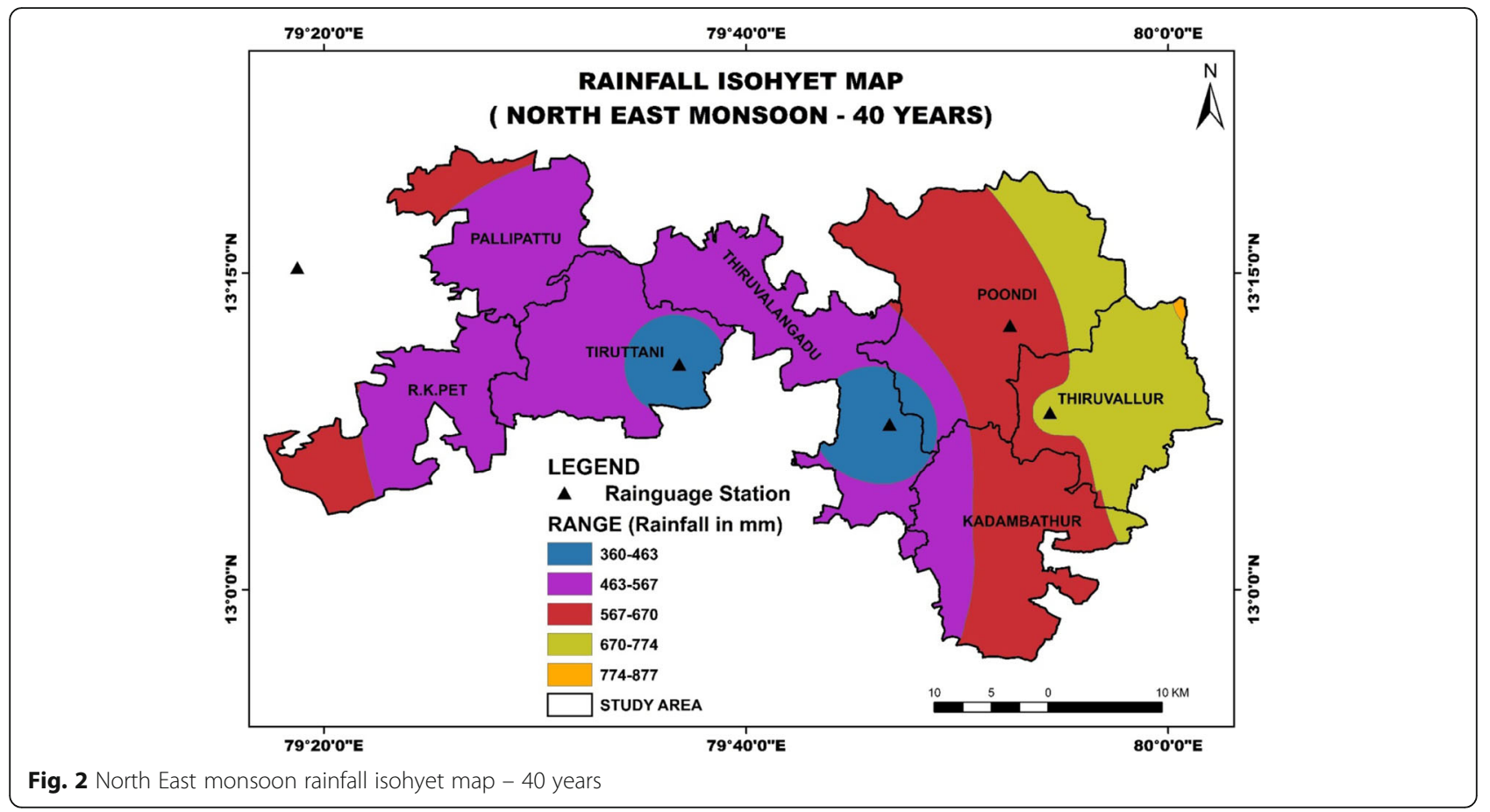

converted into raster format. These raster maps were geometrically rectified using Ground Control Points (GCP) and converted into vector format by on screen digitization method using Arc GIS 10.3 software. These vectorized themes were put into GIS environ with common projection coordinates so as to obtain better results in overlay analysis. Based on the ranking and weightage deployed in overlay analysis to each theme flood vulnerability map was derived (Kursah 2013). The phenomenon need and source of each layer is given in Table 1. Finally, the flood vulnerability is classified into high, medium and low.

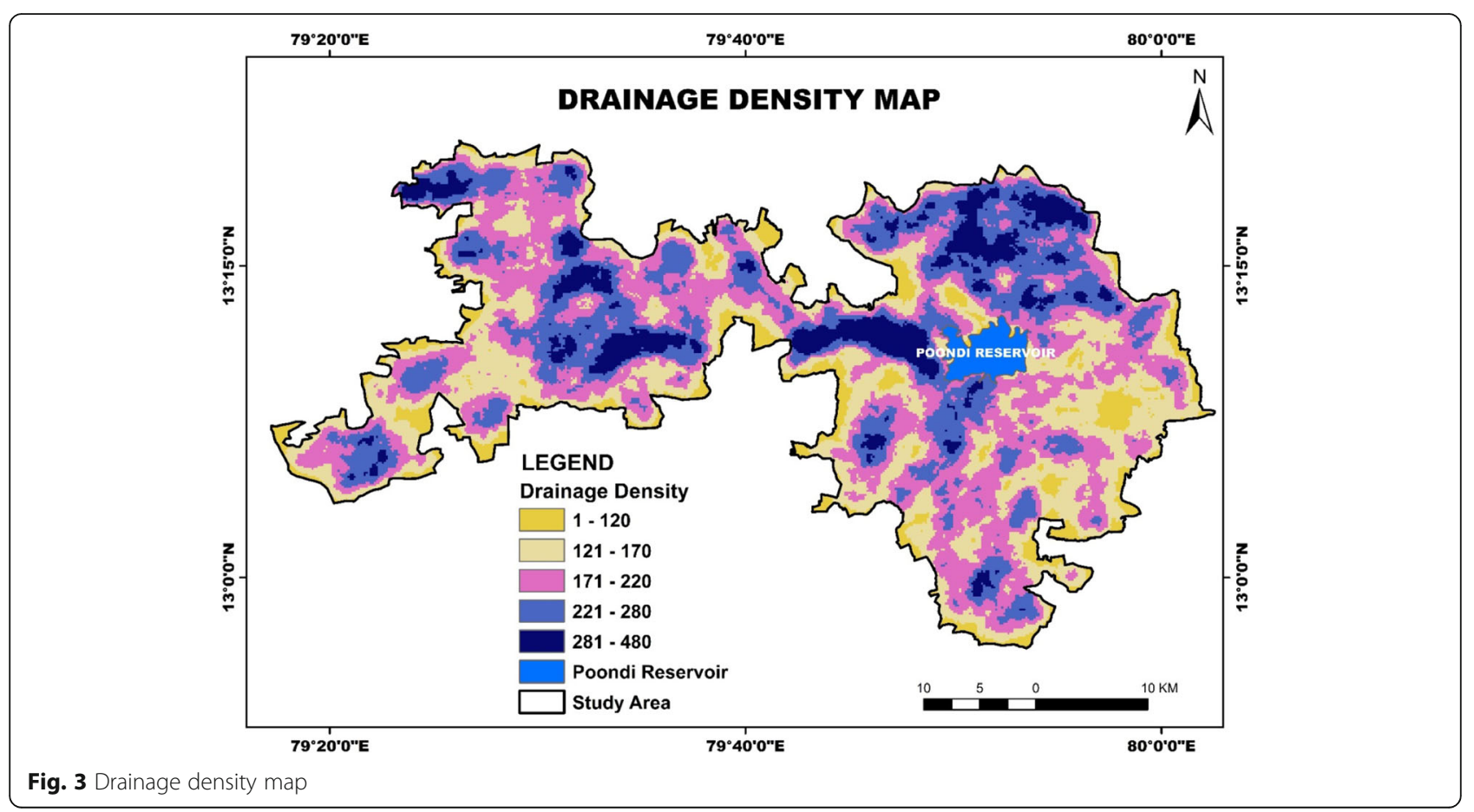




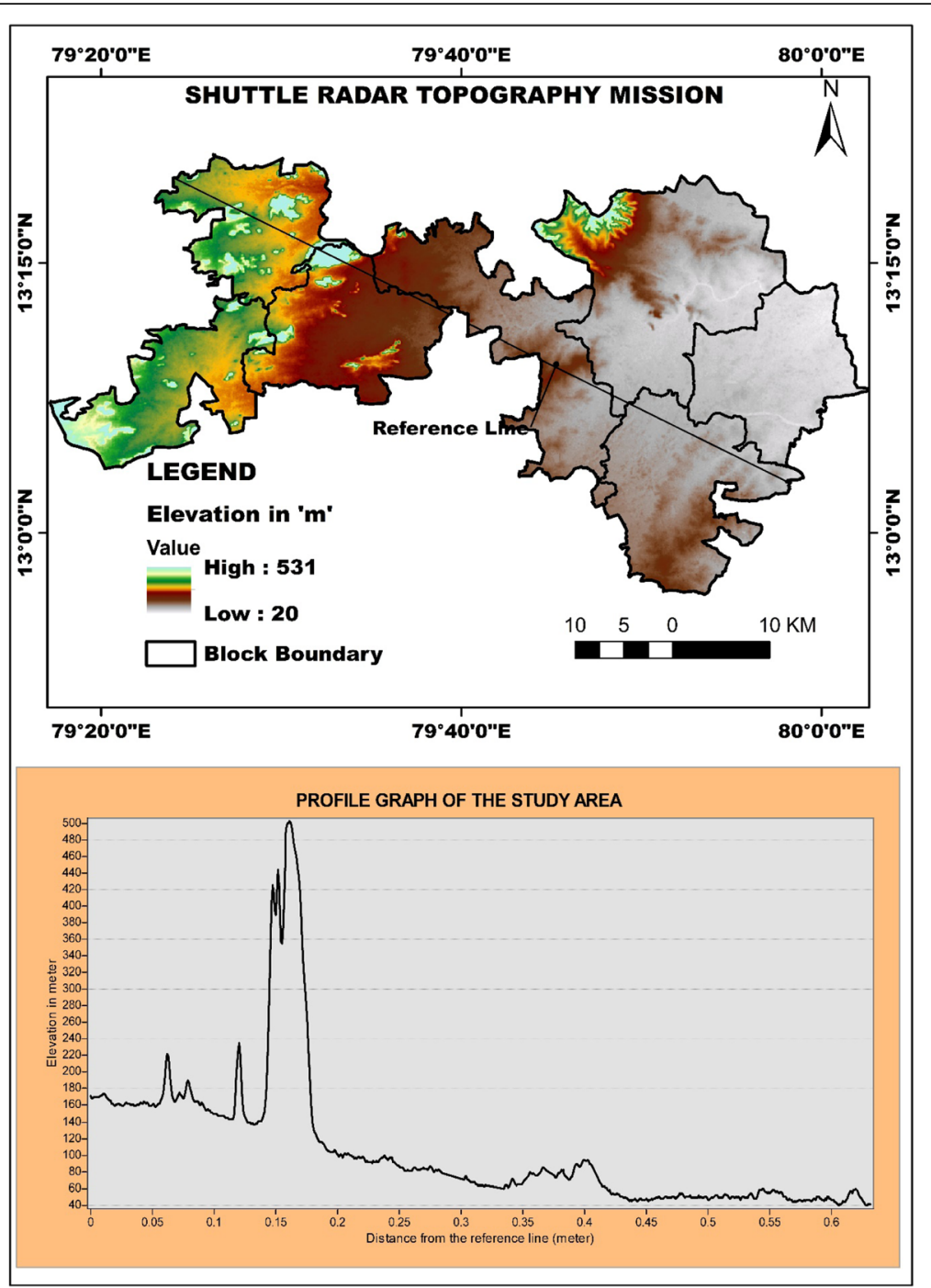

Fig. 4 SRTM and study area profile

\section{Results and discussion}

The result discusses the preparation of various resource input maps and the evaluation of possible flood vulnerable zones. Rainfall, drainage, DEM and its derivatives, geology, hydrogeology, geomorphology, land use and landcover, lineament \& intersection and zones of land subsidence have been analysed to understand the flood dynamics of the study area.

\section{Rainfall}

Rainfall data were collected from 5 rain-gauge stations namely Ponneri, Thiruvallur, Tiruttani, Thiruvalangadu and Andera Pradesh which influence to interpolate the spatial distribution of rainfall in the study area. The rural blocks of Thiruvallur District lie in the tropical monsoon zone. As the monsoons bring heavy rainfall, it improves not only the recharging of groundwater and the storage of surface water, also brings flood as the flow of water gets structed due to various obstacles. Hence, the monsoon period is hydrologically significant for water and related analysis. In case of non-monsoon, it is insignificant.

The study area receives an average annual rainfall in the range of 970 to $1100 \mathrm{~mm}$. The average north-east monsoon rainfall varies from $360 \mathrm{~mm}$ to $877 \mathrm{~mm}$. It is worth noted that the study area is often flooded during north - east (October to December) monsoon season which brings the maximum rainfall of more than $50 \%$ of the total precipitation received every year. Hence, north-east monsoon rainfall data from the year 1976 to 2015 has been analyzed to prepare the rainfall isohyet map (Fig 2) with the help of ArcView GIS Software. The rainfall 
isohyet map shows that 685 Sq.Km of the study area receives rainfall between 463 and $567 \mathrm{~mm}$. The rainfall contribution of 670 to $774 \mathrm{~mm}$ was received by more than $15 \%$ of the total study area. The maximum rainfall of $877 \mathrm{~mm}$ was recorded in the northeastern portion of Thiruvallur rain-gauge stations is noticed.

\section{Drainage, tanks and reservoir}

Drainage is an important ecosystem controlling the hazards as its densities denote the nature of the soil and its geotechnical properties (Pareta 2004). Kosasthalaiyar and Coovam rivers are the two main rivers flow through the study area. Kosasthalaiyar river originates from Panapakkam forest of Andhra Pradesh State, enters the study area through the eastern slope of the hills in Pallipattu block at an altitude of about $531 \mathrm{~m}$. Nandiyar and Nagariyar are the tributaries of Kosasthalaiyar river which are seasonal and non-perennial. The flood in the rivers are sporadic and it lasts generally for about 10 days in a year. The total length of the main river from its origin is about $155 \mathrm{~km}$ in which Poondi reservoir is located on the eastern river course. It is the major source of storage, irrigation and supplying drinking water to the nearest city. Coovum River originates near Coovum village and finally submerged with Bay of Bengal near Chepauk. Inter-connected drainage system with densely populated chain of tanks are found in the eastern part of the study area. Water flows in these rivers only when there is a rainfall. Heavy rainfall brings extreme floods during north east monsoon seasons and regularly affects the nearby towns.

Drainage density map could be derived from drainage map. Drainage map is overlaid on study area boundary to find out the ratio of total length of the drainage to total area of the study area and it is categorized. The drainage density is calculated as: $\mathrm{Dd}=\mathrm{L} /$ $A$, where $\mathrm{Dd}=$ drainage density, $\mathrm{L}=$ Total length of drainage channel $(\mathrm{Km}), \mathrm{A}=$ Total Area $\left(\mathrm{Km}^{2}\right)$. Drainage density is an inverse function of infiltration. The less the infiltration of rainfall, which conversely tends to be concentrated in surface runoff. High drainage density values are favourable for runoff, and hence less chances for flood. Higher ranks are assigned to poor drainage density area and lower ranks were given to areas with adequate drainage. The prepared drainage density map was shown in Fig 3.

\section{Elevation}

DEM is a digital representation of ground surface topography or terrain which is mainly used to observe topographic attributes allows the researchers to comprehensively examine the variables affecting a hazard in the study area (Furkuo 2010). The DEM and its derivatives play a major role in determining which areas are susceptible to flood occurrence. The elevation and the profile graph of the study have been derived from the SRTM data and is shown in the Fig 4.

The profile graph reveals that the relief falls within the range of 20 and $531 \mathrm{~m}$. It is known that water flows

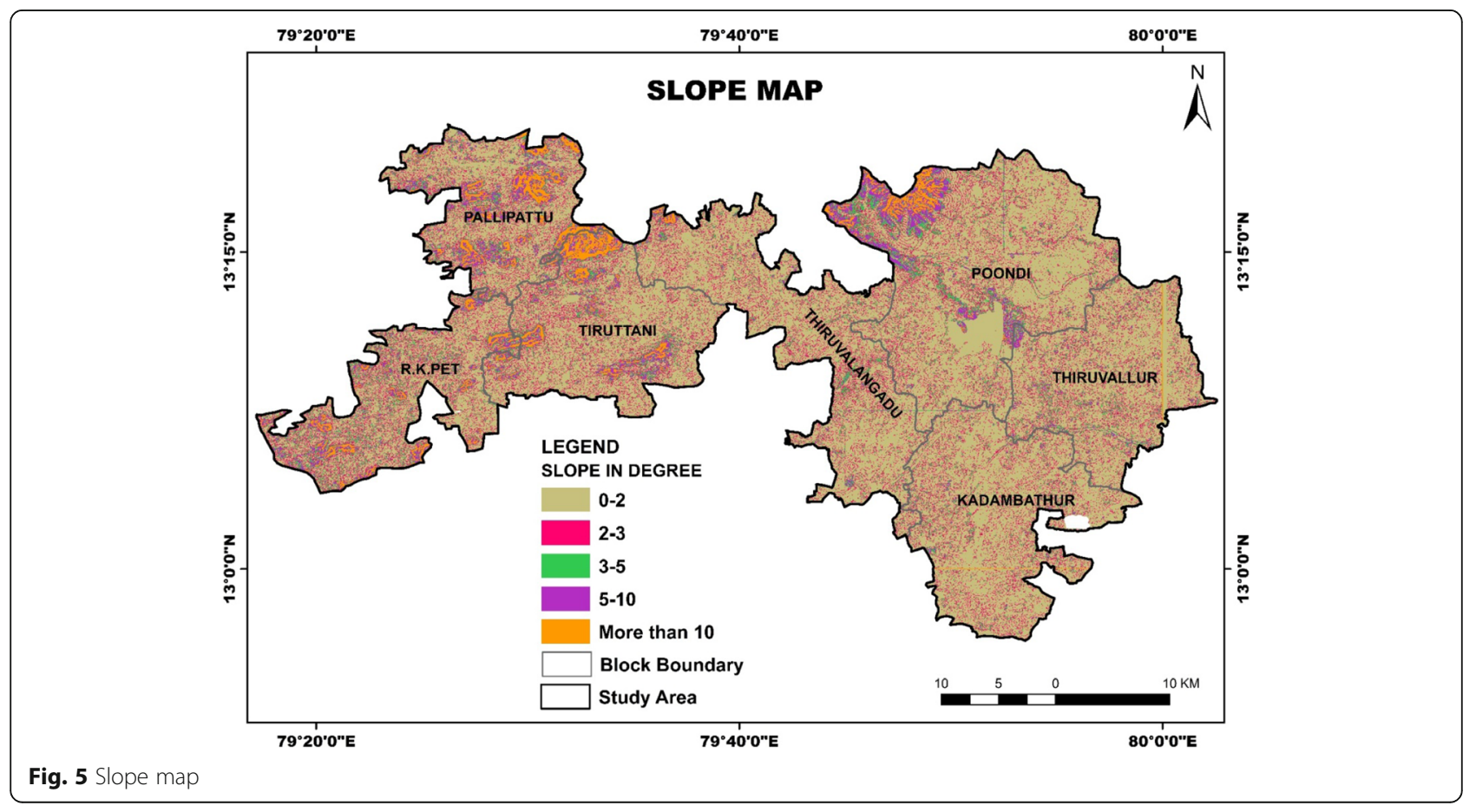




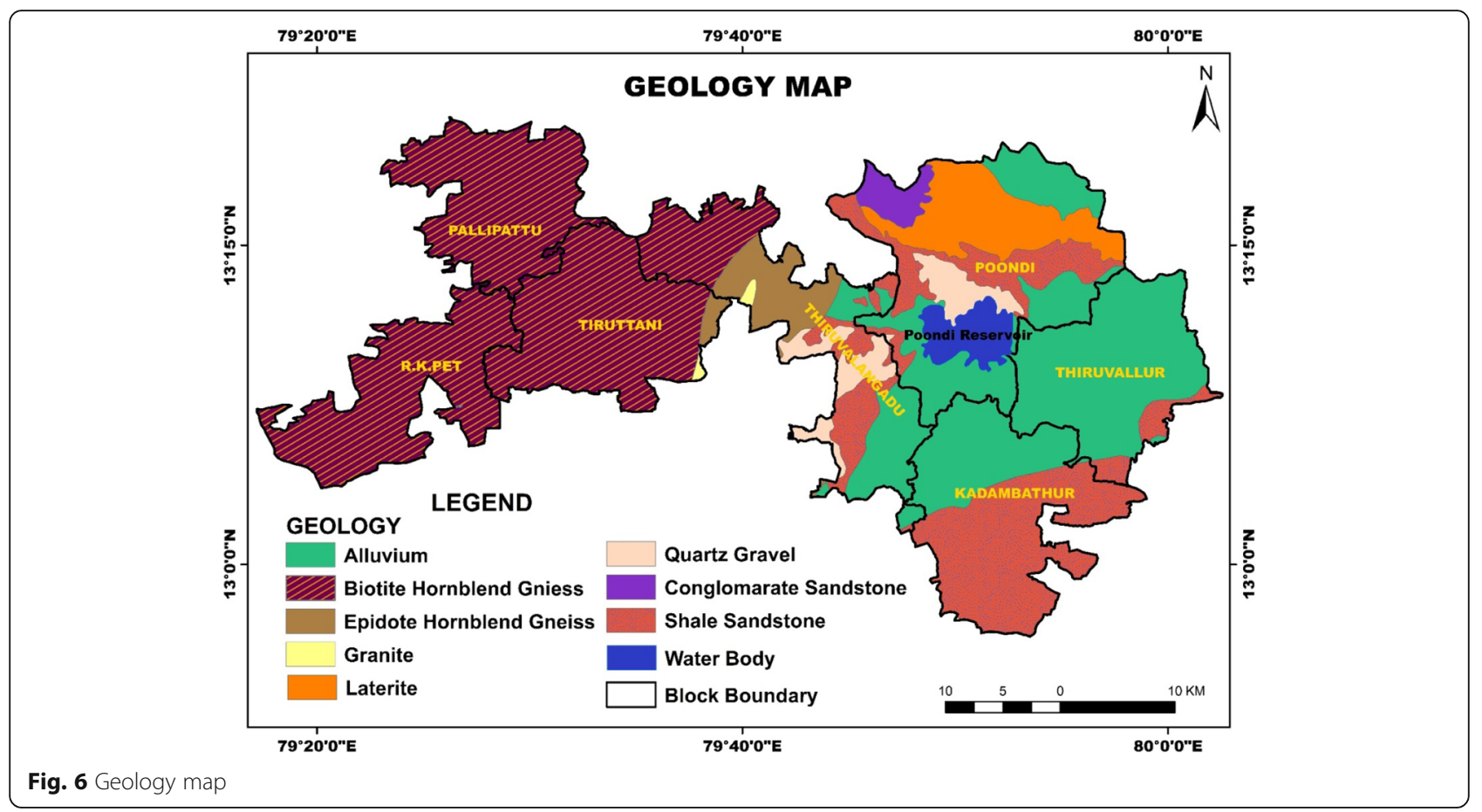

from higher to lower elevations. Low elevation areas may flood quicker than areas at higher elevation since water is accumulated more easily in the flat areas. Maximum elevation of $531 \mathrm{~m}$ (a peak) is noticed in the western slope of Tiruttani hills among the elevation ranges from $350 \mathrm{~m}$ to $530 \mathrm{~m}$ in the west and north eastern part of the study area where flooding usually does not occur.
Meanwhile, both elevation and slope influence the amount of surface runoff and infiltration.

\section{Slope}

Slope is a key indicator for the identification of flood vulnerable zones. The slope map of the study area

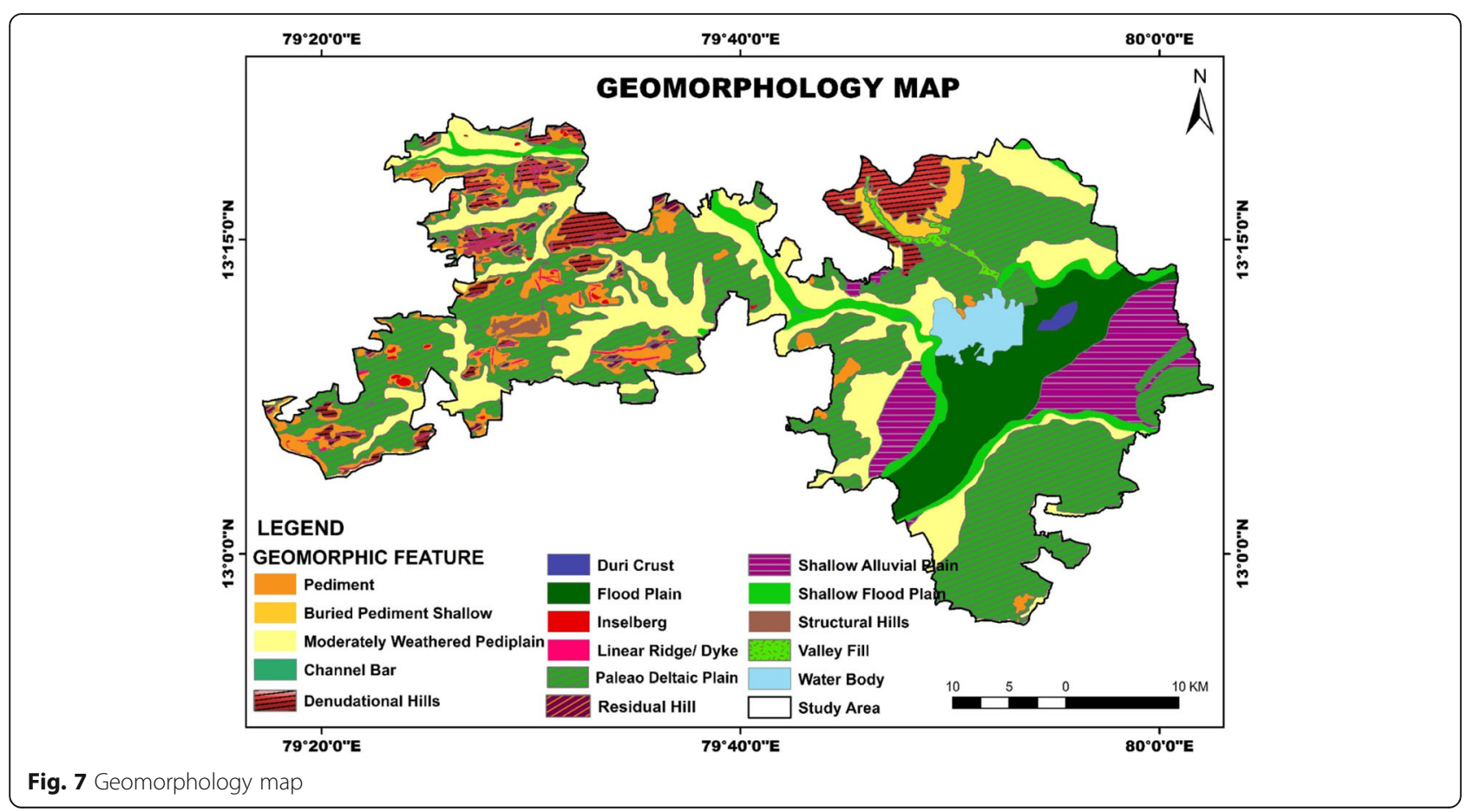




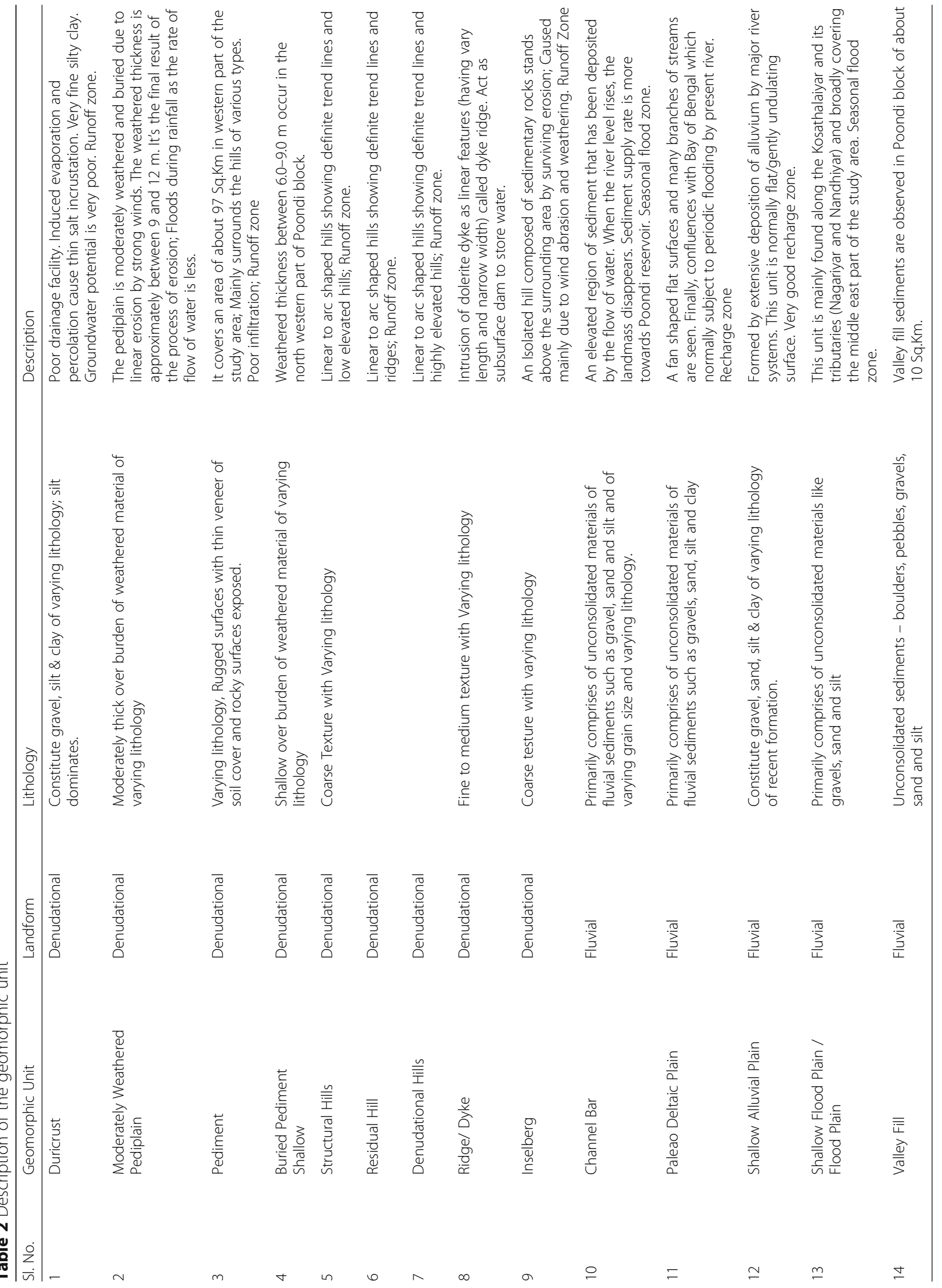




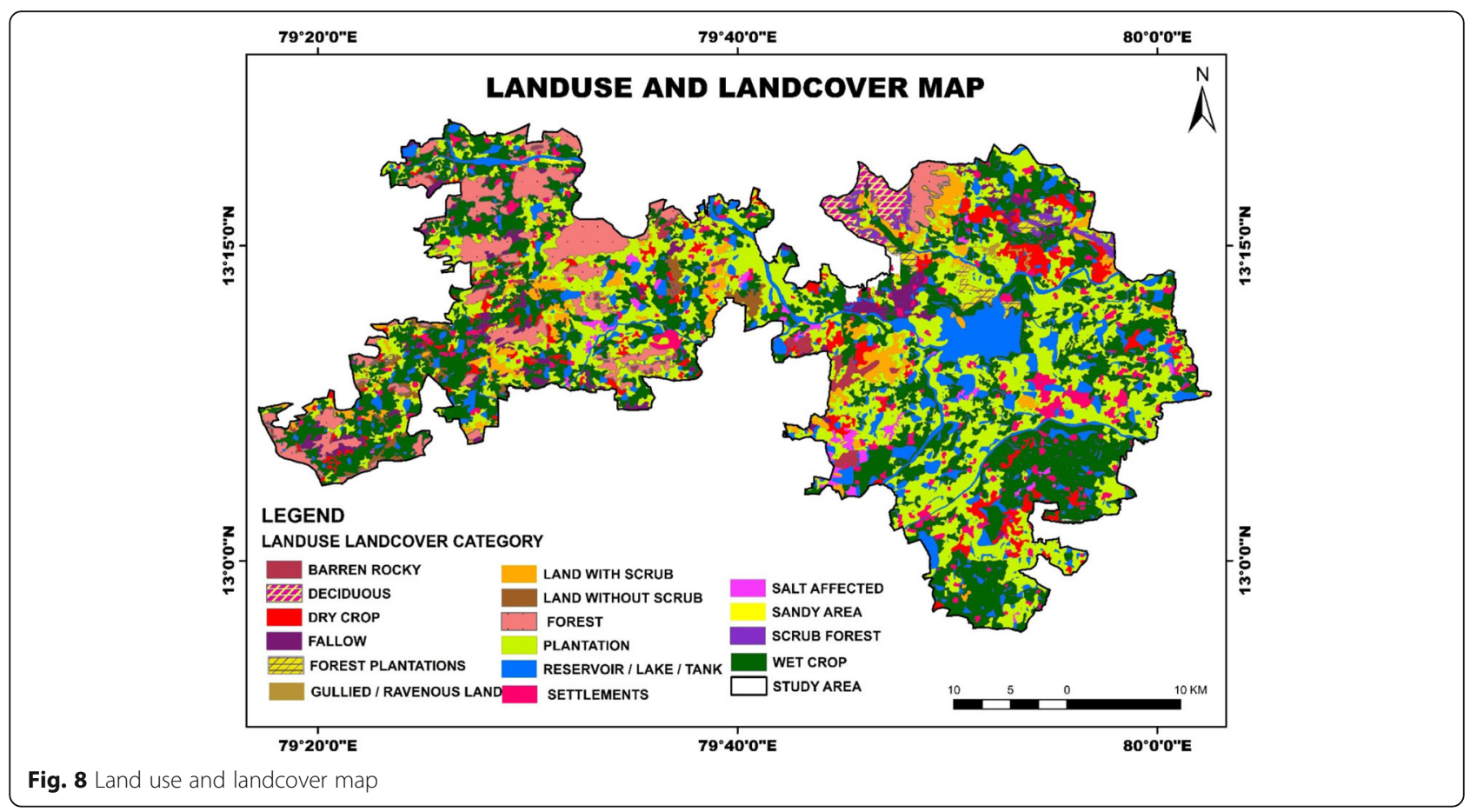

was prepared based on SRTM data using the spatial analysis tool in ArcGIS 10.3 (Fig 5). The lower the slope value flatter the terrain and higher the slope value steeper the terrain. Higher degree of slope results in rapid runoff and increased erosion rate with high flood wave velocity.

Table $\mathbf{3}$ Land use classification of the study area

\begin{tabular}{lll}
\hline S.No & Class & Area (Sq.Km) \\
\hline 1 & Barren rocky area & 18.82 \\
2 & Deciduous & 17.94 \\
3 & Dry crop & 73.22 \\
4 & Fallow Land & 41.77 \\
5 & Forest plantations & 11.72 \\
6 & Forest & 122.95 \\
7 & Gullied / Ravenous land & 2.06 \\
8 & Land with scrub & 65.35 \\
9 & Land without scrub & 16.46 \\
10 & plantation & 448.85 \\
11 & Reservoir / Lake /Tank & 162.34 \\
12 & River & 29.90 \\
13 & Settlements & 70.98 \\
14 & Salt affected & 16.28 \\
15 & Sandy area & 1.00 \\
16 & Scrub forest & 9.54 \\
17 & Wet crop & 447.89 \\
Total & & 1557.07 \\
\hline
\end{tabular}

The slope is calculated in degrees and classified into 5 categories viz., $0^{0}-2^{0}, 2^{0}-3^{0}, 3^{0}-5^{0}, 5^{0}-10^{0}$ and more than $10^{\circ}$. The map depicts that around $65 \%$ of the area is with the slope between $0^{0}$ and $2^{0}$ and more than $95 \%$ of the total study area has slope less than $10^{\circ}$ which confirms that the slope decreases gradually towards the coastal region. The drainage structure indicates the ability of the water to travel downslope with the gravity. Steep slopes are found only in the mountainous regions of denudational hill. The areas with residual and structural hills have medium slope.

\section{Hydrogeology}

Floods are part of the dynamic variation of the hydrological cycle, the basic causes of which are climatological (Green et al. 2000). Hence, a single hydrogeologic characteristic, by itself, cannot conclusively determine the flood event. Hydrologic and geologic studies therefore, should be an integral part of any flood hazard disaster studies which is applicable to other regions around the world. The occurrence and movement of surface water in hard rock is heterogeneous in nature. The lateral movement of storm water is restricted to the weathered formations of the top zones whereas the downward movement of the same looks for the fissured \& jointed features of the bottom zones. The field study confirms the presence of both hard rock and sedimentary formations.

The hydrogeological analysis shows that the hard rock formations are generally found in Tiruttani, 


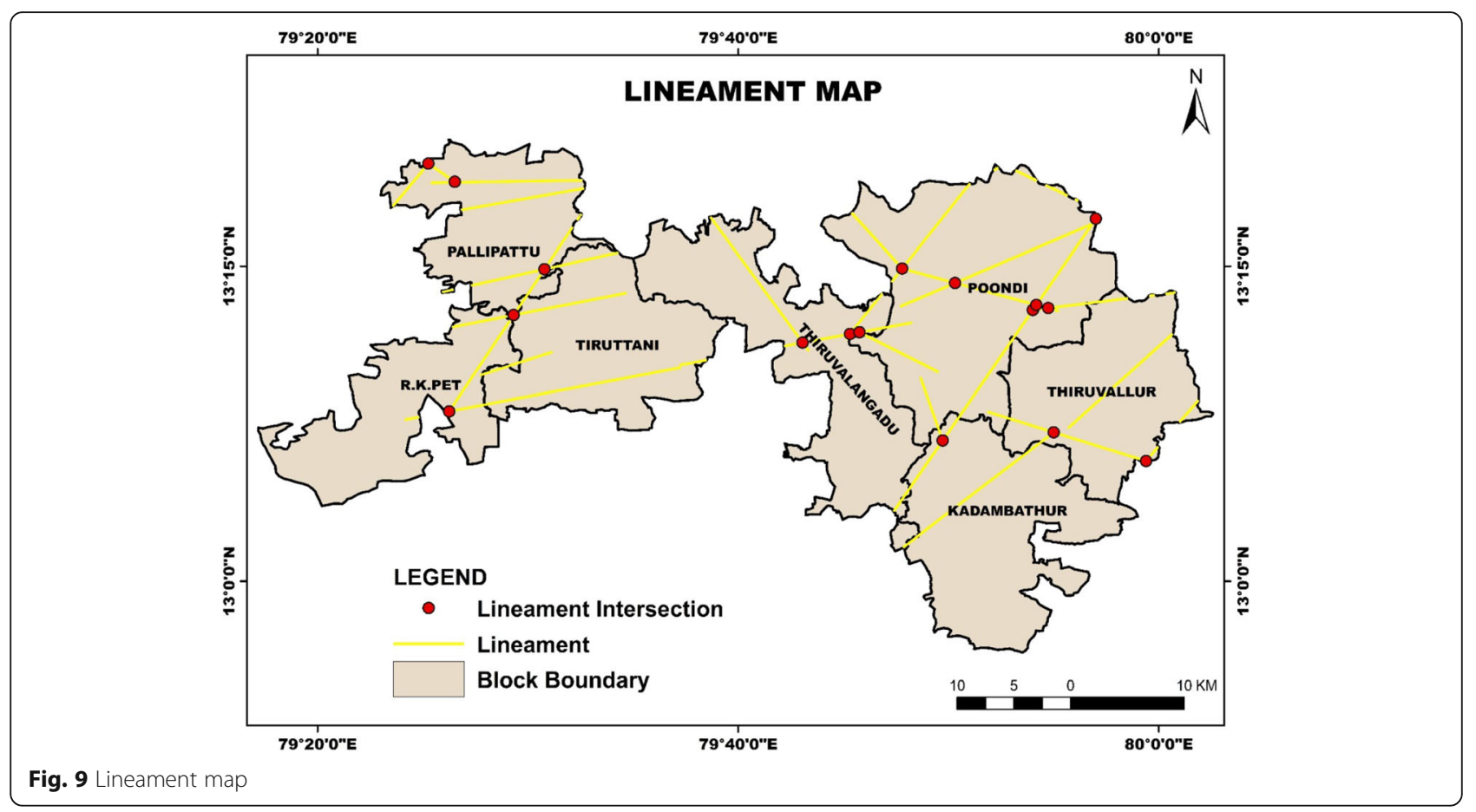

Pallipattu and R.K.Pet blocks. The top sandy soil to a depth of about 1.5 to $3 \mathrm{~m}$ followed by highly weathered formation of granite and granitic gneisses up to $7.5 \mathrm{~m}$ and well fractured formation to a depth of $30 \mathrm{~m}$ from ground level are measured in these blocks whereas the rest of the study area are covered by the sedimentary formation.

\section{Geology}

The geology of flood hazard areas is an important criterion, because it amplify / extenuate the magnitude of flood events. (Green et al. 2000, Kourgialas and Karatzas 2011, Kazakis et al. 2015). Permeable formations favour water infiltration, throughflow and groundwater flow. On the contrary, impermeable rocks such as crystalline rock favour surface runoff. (Cao et al. 2016). The study area is covered with sedimentary geological formation in the east and crystalline rocky formation in the west as shown in Fig 6. The crystalline rocks are comprised of Granite, Biotite Hornblende Gneiss, and Epidote Hornblende Gneiss which are the common country rocks in Tiruttani, RK pet and Pallipattu blocks. Tertiary, Quaternary, Gondwana - Upper-Jurassic to Cretaceous group of rocks including Alluvium and mixed sandstone occupy the western portion of the study area (GSI 2001). The conglomerate sandstones of Upper Gondwana formation are seen near Poondi border. Shale Sandstone occur as upland with Lateritic thin patches around Poondi reservoir area. Lateritic formation is porous, with cellular clay hard rock. The alluvial deposits of Kosasthalaiyar is comprised of coarse grained sands, fine grained sands, silt, gravel pebbles, sandstones and kantars. The minor portion of Poondi and Thiruvalangadu blocks are occupied by Quartz gravel.

\section{Geomorphology}

Geomorphological study is one of the most important aspects in the evaluation flood vulnerability. It plays a vital role in management of water resources and helps in various types of planning and developmental activities such as floodplain management, construction of recharge structures and routing of storm water etc. There are mainly three types of landforms and 15 geomorphic features found in the study area which are described in Fig 7. The fluvial landforms are sub divided into various geomorphic units such as Paleao Deltaic Plain, Shallow Alluvial Plain, Flood Plain, Shallow Flood Plain, Channel Bar and Valley fill. Denudational Hills, Structural Hills, Residual Hill, Inselberg, Linear Ridge/ Dyke, Pediment, Buried Pediment Shallow, moderately weathered pediplain and Duricrust are formed due to denudational activity. The characteristics, lithology, texture and static prospects of water of each geomorphic unit falling in different landforms are described in Table 2.

\section{Land-use and Landcover}

The information on natural land cover features and its usage pattern play an essential role in tutoring the 
Table 4 Structural features

\begin{tabular}{lll}
\hline Structural Features & Characteristics & Description \\
\hline Lineament & $\begin{array}{l}\text { Linear features may be a geological contact/fault// } \\
\text { shear or fractured jointed zone }\end{array}$ & $\begin{array}{l}\text { contact. } \\
\text { Lineament intersection zone }\end{array}$ \\
& $\begin{array}{l}\text { Irregular fractures with varying density criss cross } \\
\text { and conjugate system of joints }\end{array}$ & $\begin{array}{l}\text { Recharge from runoff water, water bodies acting deep } \\
\text { conductive of groundwater from long distance }\end{array}$ \\
\hline
\end{tabular}

flow dynamics of water and effective management of the water resources and flood plain in the study area.

Traditionally the land use statistics have been compiled from village records. The present land use pattern has been classified in relation to National Remote Sensing Agency (NRSA) classification (NRSA 2006). Maximum likelihood supervised classification technique has been chosen to prepare the map (Fig 8). Over 17 Land use and Land cover features were interpreted and added in the GIS data base. The details of land use classes and their corresponding area are given in Table 3.

\section{Lineament and lineament intersection}

Lineament study provides an important information on sub surface fractures that may control the movement and storage of water (Pareta 2004, 2012). Lineament map was generated using satellite imagery of IRS P6 LISS IV 2014 data (Fig 9). The structure of the rock, geology of the area, tone, texture, shape, etc. were studied using the satellite imagery and interpreted with field hydrogeological data to prepare the lineament map. The surface water movement is more along lineaments and lineament intersection zones (Periyasamy et al. 2014). Lineament map was overlaid on the other thematic maps for targeting flood vulnerable zones. The structural feature and the characteristics are shown in Table 4.

\section{Zones of land subsidence}

As the zones of land subsidence are generally prone for flooding and Tamil Nadu has also been proved to be tectonically active. The lineaments were integrated with various drainage anomalies, especially the compressed meanders confined within the sub parallel lineaments and the eyed drainages along with it (Fig 10). Thus, GIS database was generated on the lineaments and there from the zones of land subsidence were brought out.

\section{Soil}

Soil is one of the natural resources, which has the most direct impact on flood as they control the amount of water that can infiltrate into the soil and hence the amount of water which becomes flow (Nicholls and Wong 1990). The prepared soil map is shown in Fig 11. Soil surveys provide nature of soils, their extent and their characteristics. The major soil types found in the study area are Alfisol, Entisol,

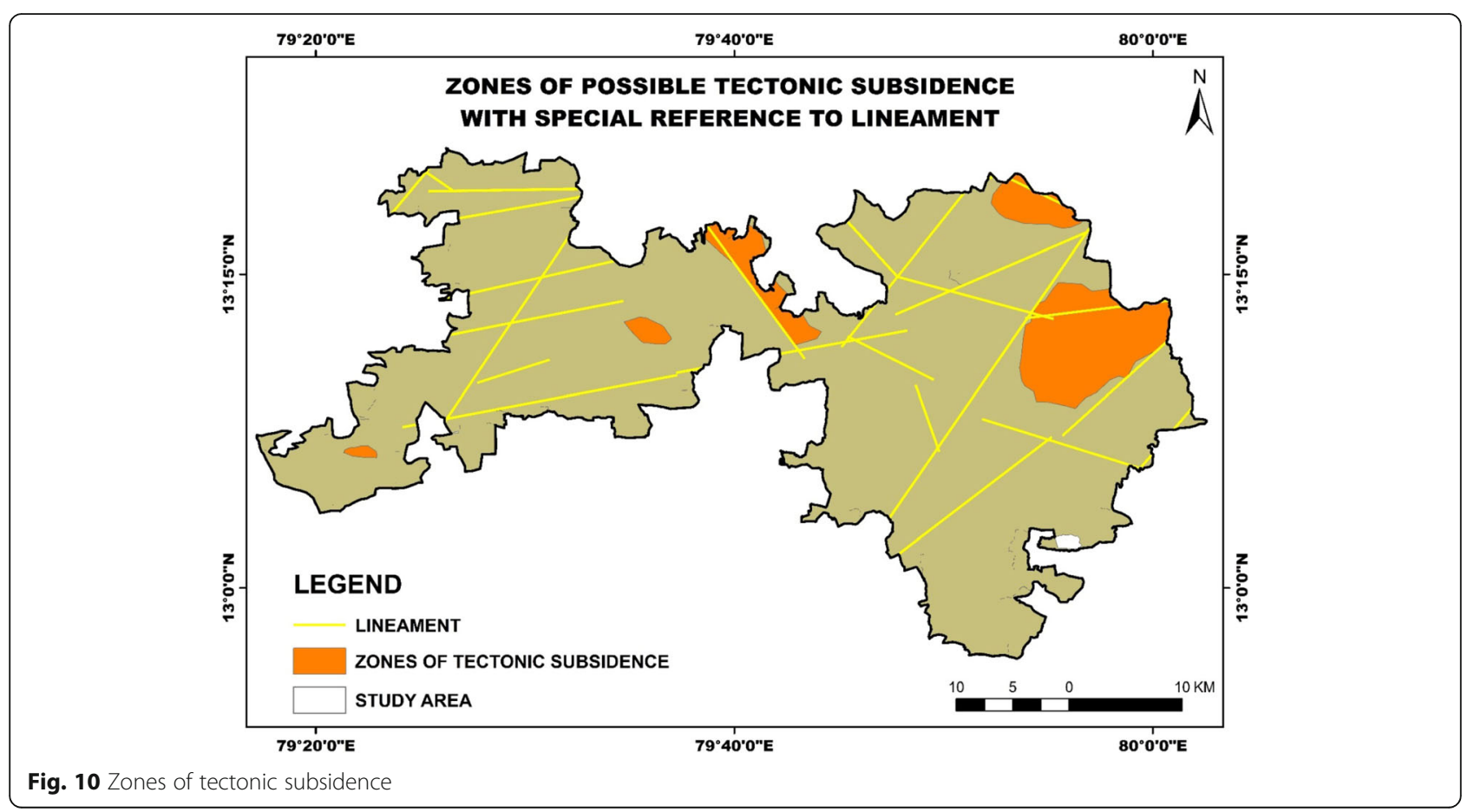




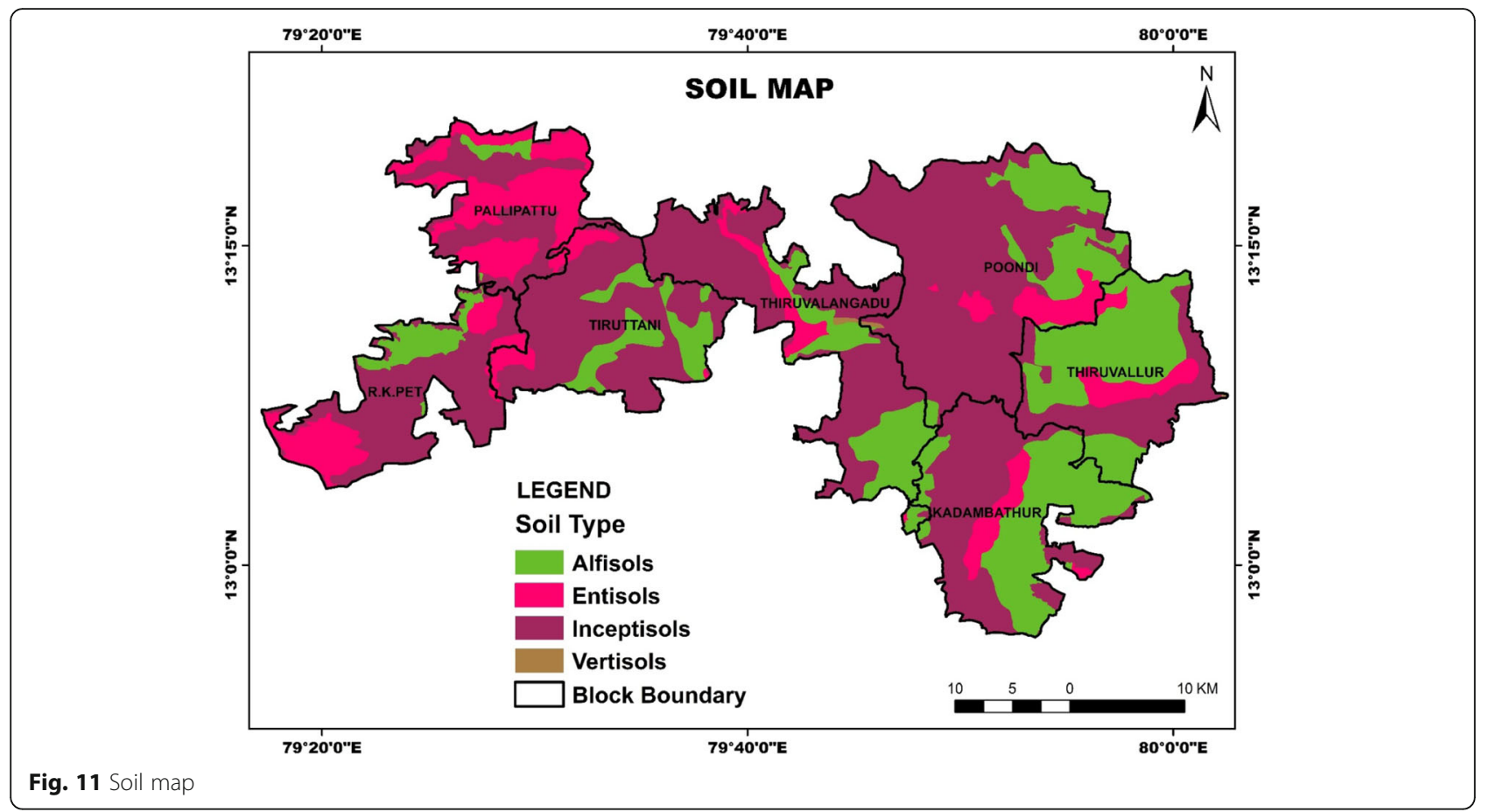

Inceptisol and Vertisol. Due to different stage of weathering of parent material, the soil types are met with in combination.

The structure and infiltration capacity of soils will also have an important impact on the efficiency of the soil to acts as a sponge and soak up water. Different types of soils have differing water holding and infiltration capacities which consequently affect flood susceptibility (Nyarko 2002). The chance of flood hazard increases with decrease in soil infiltration capacity, which causes increase in surface runoff. When water is supplied at a rate that exceeds the soil's infiltration capacity, it moves down slope as runoff on sloping land and can lead to flooding (Lowery et al. 1996). On the whole, the study area shows runoff from intense rainfall is likely to be faster with vertosols than with entisols. The mapping unit and the soil classifications are tabulated in the Table 5.

\section{Evaluation of possible flood vulnerable zone}

GIS plays a more key role in analysing the flood vulnerability. Arc GIS and Arc view were used to create database for spatial and non-spatial data. Raster overlay analysis is a necessary component to bring together data representing the Phenomenon. Using the Boolean logic rules to combine different layers is one of the easiest methods, through "Yes" or "No" rules. Most Boolean logical based overlay procedures in GIS do not allow for the fact that variables may not be equally important and the decisions about threshold values are often subjective. Hence, to quantify the parameters in the analysis Mathematical Overlay method was adopted. The final result is in the form of a raster layer, where each grid cell acquired a value through the productive overlay process. The higher the value of the grid cell, the more preferred the cell is prone to highly vulnerable zone.

Table 5 Soil classification

\begin{tabular}{lll}
\hline Mapping unit & Description & Classification \\
\hline Alfisols & Moderately deep, well drained, gravelly clay soils on gently sloping lands, & Clayey-skeletal, mixed, Typic Rhodustalfs. \\
& moderately eroded; associated with moderately shallow, well drained & \\
& gravelly loam soils. & \\
Entosols & Moderately shallow, well-drained, gravelly loam soils on undulating hills, \\
& severely eroded; associated with shallow, well-drained, gravelly loam soils. & Loamy skeletal, mixed, Typic Ustorthents. \\
Inceptisols & Shallow, well drained, gravelly clay soils on gently sloping lands, moderately \\
& eroded; associated with moderately shallow, well drained, gravelly clay soils. & Clayey skeletal, mixed, Rhodic Paleustalfs. \\
Vertisols & Very deep, moderately well drained, calcarious, cracking clay soils on gently & Fine, Montmorillonitic, Entic Chromusterts. \\
& sloping lands, slightly eroded. & \\
\hline
\end{tabular}


Table 6 Weights, classes and scores for map layers

\begin{tabular}{|c|c|c|c|c|}
\hline S.No & Map Layer & Classes & Rank & Weightage (\%) \\
\hline \multirow[t]{5}{*}{1.} & \multirow[t]{5}{*}{ Rainfall in $\mathrm{mm}$} & $360-463$ & 1 & \multirow[t]{5}{*}{19.44} \\
\hline & & $463-567$ & 2 & \\
\hline & & $567-670$ & 3 & \\
\hline & & $670-774$ & 4 & \\
\hline & & $774-877$ & 5 & \\
\hline \multirow[t]{5}{*}{2.} & \multirow[t]{5}{*}{ Drainage Density } & $1-120$ & 5 & \multirow[t]{5}{*}{15.18} \\
\hline & & $121-170$ & 4 & \\
\hline & & $171-220$ & 3 & \\
\hline & & $221-280$ & 2 & \\
\hline & & $281-480$ & 1 & \\
\hline \multirow[t]{5}{*}{3.} & \multirow[t]{5}{*}{ Elevation in $\mathrm{M}$} & $<50$ & 5 & \multirow[t]{5}{*}{12.14} \\
\hline & & $50-150$ & 4 & \\
\hline & & $151-180$ & 3 & \\
\hline & & $181-250$ & 2 & \\
\hline & & $>250$ & 1 & \\
\hline \multirow[t]{5}{*}{4.} & \multirow[t]{5}{*}{ Slope } & $0-2$ & 5 & \multirow[t]{5}{*}{11.71} \\
\hline & & $2-3$ & 4 & \\
\hline & & $3-5$ & 3 & \\
\hline & & $5-10$ & 2 & \\
\hline & & More than 10 & 1 & \\
\hline \multirow[t]{8}{*}{5.} & \multirow[t]{8}{*}{ Geology } & Alluvium & 4 & \multirow[t]{8}{*}{05.40} \\
\hline & & Biotite Hornblende Gneiss & 2 & \\
\hline & & $\begin{array}{l}\text { Epidote Hornblende } \\
\text { Gneiss }\end{array}$ & 3 & \\
\hline & & Granite & 2 & \\
\hline & & Laterite & 3 & \\
\hline & & Quartz Gravel & 2 & \\
\hline & & Conglomerate Sandstone & 1 & \\
\hline & & Shale Sandstone & 2 & \\
\hline \multirow[t]{14}{*}{6.} & \multirow[t]{14}{*}{ Geomorphology } & Duricrust & 3 & \multirow[t]{14}{*}{04.73} \\
\hline & & $\begin{array}{l}\text { Moderately Weathered } \\
\text { Pediplain }\end{array}$ & 4 & \\
\hline & & Pediment & 4 & \\
\hline & & Buried Pediment Shallow & 5 & \\
\hline & & Structural Hills & 1 & \\
\hline & & Residual Hill & 1 & \\
\hline & & Denudational Hills & 1 & \\
\hline & & Ridge/ Dyke & 2 & \\
\hline & & Inselberg & 1 & \\
\hline & & Channel Bar & 3 & \\
\hline & & Paleao Deltaic Plain & 4 & \\
\hline & & Shallow Alluvial Plain & 4 & \\
\hline & & $\begin{array}{l}\text { Shallow Flood Plain } \\
\text { /Flood Plain }\end{array}$ & 5 & \\
\hline & & Valley Fill & 2 & \\
\hline \multirow[t]{2}{*}{7.} & \multirow{2}{*}{$\begin{array}{l}\text { Land use and } \\
\text { landcover }\end{array}$} & Barren rocky area & 2 & \multirow[t]{2}{*}{13.11} \\
\hline & & Deciduous & 1 & \\
\hline
\end{tabular}

Table 6 Weights, classes and scores for map layers (Continued)

\begin{tabular}{|c|c|c|c|c|}
\hline S.No & Map Layer & Classes & Rank & Weightage (\%) \\
\hline & & Dry crop & 2 & \\
\hline & & Fallow Land & 4 & \\
\hline & & Forest plantations & 2 & \\
\hline & & Forest & 1 & \\
\hline & & Gullied / Ravenous land & 4 & \\
\hline & & Land with scrub & 3 & \\
\hline & & Land without scrub & 3 & \\
\hline & & Plantation & 2 & \\
\hline & & Reservoir /Lake /Tank & 5 & \\
\hline & & River & 5 & \\
\hline & & Settlements & 3 & \\
\hline & & Salt affected & 2 & \\
\hline & & Sandy area & 1 & \\
\hline & & Scrub forest & 1 & \\
\hline & & Wet crop & 2 & \\
\hline \multirow[t]{2}{*}{8.} & \multirow{2}{*}{$\begin{array}{l}\text { Lineaments \& } \\
\text { Intersection }\end{array}$} & Lineament & 4 & 06.59 \\
\hline & & $\begin{array}{l}\text { Lineament intersection } \\
\text { zone }\end{array}$ & 5 & \\
\hline 9. & $\begin{array}{l}\text { Zones of Tectonic } \\
\text { Subsidence }\end{array}$ & Land subsidence & 3 & 07.43 \\
\hline \multirow[t]{4}{*}{10.} & Soil & Alfisols & 2 & 04.27 \\
\hline & & Entosols & 4 & \\
\hline & & Inceptisols & 3 & \\
\hline & & Vertisols & 1 & \\
\hline
\end{tabular}

The flood vulnerable zonation map has been generated by integrating the spatial and non- spatial data of Rainfall, Drainage, Elevation and its derivatives, Geology, Geomorphology, Land use and landcover, Lineament and their intersection, Zones of tectonic subsidence with special reference to lineament and Soil. After determining criteria value ranges, the ranking of the class values from 1to 5 is assigned with respect to scientific codes and assumptions. (Mohamed 2015). Appropriate weightages were given based on the properties and characteristics of the layers shown in Table 6.

\section{Result}

By analysing the sufficient parameters in the GIS platform, the probable flood prone zones were identified (Fig 12). Assessment of the character of flood hazards and the extent of flood-prone areas on the piedmonts around the White Tank mountains report also describes typical differences in the character and distribution of flood hazards in the upper, middle, and lower piedmont areas of Arizona (Field and Pearthree 1992). On the other hand, the flood hazard index of Najran city of Saudi Arabia has been classified in low, 


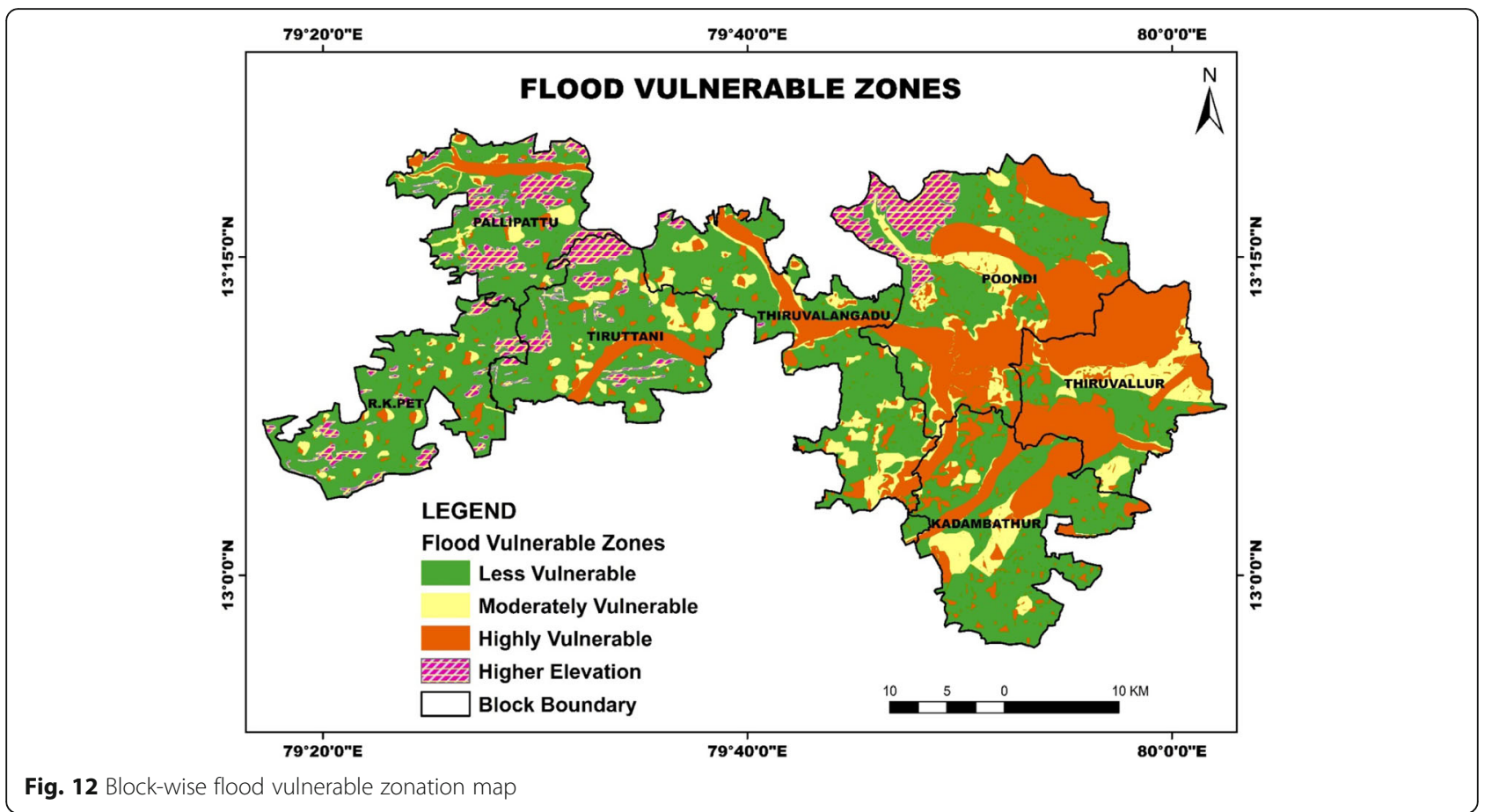

moderate, high and very high. The final hazard map was overlaid with the zone boundaries layer to obtain high risk flood zones. The affected population number and land area were determined and compared. (Elkhrachy 2015). Likewise, the block layer of the study area is overlaid with flood vulnerable zones map. Based on the outcome of the result, the vulnerability was evaluated and tabulated in Table 7. It is observed that the vulnerability of the study area is classified viz., Highly Vulnerable, Moderately Vulnerable, Less Vulnerable and Elevated Area with its aerial extent of 426.47, 181.57, 832.25 and $116.78 \mathrm{Sq}$. Km. respectively.

\section{Conclusion and recommendation}

The research presented in this article formulates an efficient methodology to accurately delineate the probable flood vulnerable zones in the rural blocks of Thiruvallur district. The results were validated by the flood hazard profile of the district. Special investigation is required in higher elevated and less vulnerable areas to find the suitable site for the construction shelters mainly, after analysing no vulnerable areas within the less vulnerable zones. Flood early warning system and safe flood evacuation routes are recommended for the blocks which fall in moderate and highly vulnerable zones. Based on the study the following conclusions and recommendations were arrived.

\section{Non - structural measures}

A. By analysing, the sufficient parameters in the GIS platform, the flood vulnerability map is generated, and the block boundaries were

Table 7 Block-wise spatial distribution of flood vulnerable zones

\begin{tabular}{|c|c|c|c|c|c|c|}
\hline \multirow[t]{2}{*}{ S.No } & \multirow[t]{2}{*}{ Block Name } & \multicolumn{5}{|c|}{ Area in Sq.Km } \\
\hline & & Block Area & Highly Vulnerable & Moderately Vulnerable & Less Vulnerable & Elevated Area \\
\hline 1 & Pallipattu & 163.70 & 18.79 & 10.94 & 98.90 & 35.07 \\
\hline 2 & Poondi & 347.85 & 143.04 & 42.83 & 123.37 & 38.56 \\
\hline 3 & Tiruttani & 201.19 & 25.36 & 18.80 & 133.22 & 23.90 \\
\hline 4 & Thiruvallur & 194.15 & 114.37 & 37.67 & 42.11 & 0.00 \\
\hline 5 & R.K.pet & 173.43 & 10.71 & 6.83 & 138.83 & 17.15 \\
\hline 6 & Kadambathur & 235.69 & 62.80 & 34.20 & 138.55 & 0.00 \\
\hline \multirow[t]{2}{*}{7} & Thiruvalangadu & 241.06 & 51.40 & 30.30 & 157.27 & 2.09 \\
\hline & Total & 1557.07 & 426.47 & 181.57 & 832.25 & 116.78 \\
\hline
\end{tabular}


overlaid. The percentage of highly vulnerable area in Thiruvallur, Poondi and Kadambathur blocks are 59, 41 and 26. Long term flood mitigation and management plan shall be developed in these blocks by quantifying the runoff and stagnant floodwater. The blocks having high and moderate vulnerability needs special investigation to develop the plan.

B. The centralized database system for the region shall be established by collecting all relevant data from various agencies, departments, institutions etc. This common database may enable the researchers to conduct a micro level study through which site-specific mitigation plan could be arrived within the span of time.

C. To minimize flood damage to properties, infrastructure and the environment, the factors associated with flood risk such as flow velocity, upstream inundation, erosion rate and the impacts of environment shall be thoroughly studied. Flood plain management policy must be enacted to preserve the eco-system since land use within flood plain involves trades off between flood risk and development. (Bishaw 2012).

\section{Structural measures}

Artificial Recharge \& Rainwater Harvesting Structure - The study area lies within the tropical monsoon zone. As the monsoon period brings heavy rainfall, it improves the recharging of groundwater as well as storage of surface water. Hence, the monsoon period (June to November) is hydrologically significant for water resources and related analysis. From the study it is recommended to quantify the surface and groundwater during summer. Based on the hydro-geological investigations, the location specific rainwater harvesting \& artificial recharge structures shall be built mainly in the drought affected, dry aquifer and water deficit regions which may ease the floodwater to percolate into the ground which in turn improve the groundwater potential.

De-siltation of Tanks - Tanks (Surface water bodies) are the main source for irrigation and drinking water in the study area. Siltation of the tank not only reduces the storage capacity, but also increases flood risk. On one hand, when the tank reaches its limit, the authorities are forced to open the tank, on the other hand, dam failure may happen if the structure is weak. On the whole, this may cause the situation even worse if the area is already flooded or during heavy rain or cyclone or unstable air. This intricate hydro-dynamic network may invite multi disaster scenario in which the probability of life and property loss are high.
Unfortunately the area of no vulnerable land is 116.78 Sq.Km which is only $7.5 \%$ whereas the sum of high and moderate vulnerable zones occupy about $50 \%$ of the total study area. Hence, de-siltation and strengthening of tanks are recommended to achieve their full capacity of storage and robust water storage system. Steps have to be taken to minimize soil erosion in the catchments area to avoid siltation.

Removal of Obstacles and Construction of waterways Rapid urbanization and unplanned constructions in the waterways disturb the natural surface runoff. Consequently, floodwater finds another possible irregular route through settlements or environmentally sensitive areas to reach its destination; Otherwise the huge stagnant rainwater may result in evacuation, transport and communication failure, insect bite and provides way for contagious diseases. Hence, it is recommended to remove the obstacles in the waterways, widen the riverbank and construct waterflow channel in the water stagnant areas and the same shall be adopted as one of the criteria in the land use planning of the flood prone area. New land development should therefore be prohibited.

\section{Abbreviations \\ DEM: Digital elevation model; GCP: Ground control points; GIS: Geographic information system; GSI: Geological survey of India; LISS: Linear imaging self scanning; NRSA: National remote sensing agency; NRSC: National remote sensing centre; SRTM: Shuttle radar topographic mission}

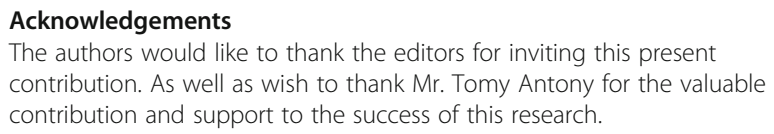

Authors' contributions

PP and MS collected data from various sources. PP performed the assessment and drafted the manuscript. MMY provided skills development, comments and suggestions during data compilation, analysis and results interpretation. MS provided software and methods guidance to develop the thematic maps. All authors read and approved the final manuscript.

Ethics approval and consent to participate

Not applicable.

\section{Competing interests}

The authors declare that they have no competing interests.

\section{Publisher's Note}

Springer Nature remains neutral with regard to jurisdictional claims in published maps and institutional affiliations.

\section{Author details}

${ }^{1}$ Department of Civil Engineering, SRM University, Kattankulathur, 603203 Kancheepuram, Tamil Nadu, India. ${ }^{2}$ Department of Geography and Urban 
Planning, UAE University, Al Ain, UAE. ${ }^{3}$ Department of Applied Geology, University of Madras, Chepauk, Chennai, India.

Received: 5 March 2018 Accepted: 30 October 2018

Published online: 14 November 2018

\section{References}

Ajin, R.S., R.R. Krishnamurthy, M. Jayaprakash, and P.G. Vinod. 2013. Flood hazard assessment of Vamanapuram River Basin, Kerala, India: an approach using remote sensing \& GIS techniques. Pelagia research library. Advances in Applied Science Research 4 (3): 263-274.

Bishaw, Kebede. 2012. Application of GIS and remote sensing techniques for flood Hazard and risk assessment: The case of Dugeda bora Woreda of Oromiya regional state, Ethiopia. Berlin: Paper presented at the Berlin Conference on the Human Dimensions of Global Environmental Change.

Cao, Chen, Peihua Xu, Yihong Wang, Jianping Chen, Lianjing Zheng, and Cencen Niu. 2016. Flash flood hazard susceptibility mapping using frequency ratio and statistical index methods in coalmine subsidence areas. Sustainability 8, 948: 1-18. https://doi.org/10.3390/w6061515.

Danumah, Jean Homian, Samuel Nii Odai, Bachir Mahaman Saley, Joerg Szarzynski, Michael Thiel, Adjei Kwaku, Fernand Koffi Kouame, and Lucette You Akpa. 2016. Flood risk assessment and mapping in Abidjan district using multi-criteria analysis (AHP) model and geoinformation techniques, (cote d'ivoire). Geoenvironmental Disasters 3 (10): 1-13.

Elkhrachy, Ismail. 2015. Flash flood Hazard mapping using satellite images and GIS tools: a case study of Najran City, Kingdom of Saudi Arabia (KSA). The Egyptian Journal of Remote Sensing and Space Sciences 18: 261-278 https:// doi.org/10.1016/j.ejrs.2015.06.007.

Field, John J., and Philip A. Pearthree. 1992. Geologic mapping of flood Hazards' in Arizona: An example from the white Tank Mountains area. Maricopa County by Arizona Geological Survey Open-File Report: 91-10. http://repository. azgs.az.gov/uri_gin/azgs/dlio/907.

Furkuo, E.K. 2010. Journal of Environmental science and Engineering 52(2): 81-92.

Green C H., Parker, D. J. and Tunstall, S. M. (2000) Assessment of flood control and management options. WCD thematic review IV.4 prepared as an input to the world commission on dams, Cape Town, http://citeseerx.ist.psu.edu/ viewdoc/download?doi=10.1.1.467.4860\&rep=rep1\&type=pdf.

GSI (2001) Geological survey of India, district resource map, Thiruvallur District, Tamil Nadu, India.

Kazakis, Nerantzis, loannis Kougias, and Thomas Patsialis. 2015. Assessment of flood hazard areas at a regional scale using an index-based approach and analytical hierarchy process: application in Rhodope-Evros region, Greece. Science of the Total Environment 538: 555-563.

Kourgialas, N.N., and G.P. Karatzas. 2011. Flood management and a GIS modelling method to assess flood- case study. Hydrological Sciences Journal 56 (2): 212-225.

Kursah, Matthew Biniyam. 2013. Application of GIS in flood detection for road infrastructure planning in north-eastern corridor of northern Ghana. International Journal of Applied Science and Technology 3 (5): 94-106.

Lowery, B., W.J. Hickey, M.A. Arshad, and R. Lal. 1996. Soil water parameters and soil quality. In Methods for assessing soil quality, 1999, ed. J.W. Doran and A.J. Jones. Madison: Reprint Soil Science Society of America.

Mili, Nitashree, and Shukla Acharjee. 2014. The importance of geomorphology in understanding natural hazards with special reference to hazards of the Dhansiri River basin in the Golaghat District of Assam, India. Global Perspectives on Geography 2: 1-8.

Mohamed, Yagoub Mohamed. 2015. Spatio - Temporal and hazard mapping of earthquake in UAE (1984 - 2012): Remote sensing and GIS application. Geoenvironmental Disaster 2 (1): 1-14.

Nicholls, N., and K.K. Wong. 1990. Journal of Climate 3: 163-170.

Noble, Rosemary, J. Reshma, Rajesh Raghunath, and P. Vineetha. 2016. Flood Hazard zonation of Vamanapuram River basin, Trivandrum, India using remote Sensingand GIS techniques. International Journal of applied Remote Sensing and GIS. ISSN 2394 - 8698 (P), ISSN 2395 - 4388 (O). 3(1): 26-33.

NRSA (2006) National Land use and land cover mapping using multi-temporal AWifs data. Remote Sensing and GIS Applications area Hyderabad, India.

NRSC (2011), Resourcesat-2, data users' handbook, national remote sensing Centre, Indian space research organization.

Nyarko, B.K. 2002. Application of a rational model in GIS for flood risk assessment in Accra. Journal of Spatial Hydrology 2 (1): 1-14.
Ouma, Yashon O., and Ryutaro Tateishi. 2014. Urban flood vulnerability and risk mapping using integrated multi-parametric AHP and GIS: Methodological overview and case study assessment. Water 6: 1515-1545. https://oi.org/10.3390/w6061515.

Pareta, K. 2004. Hydro-Geomorphology of Sagar District (M.P.): A Study through Remote Sensing Technique. Bhopal: Abstracts of the XIX M. P. Young Scientist Congress, Madhya Pradesh Council of Science \& Technology.

Pareta, K (2012) Hydromorphological study of Karawan watershed using GIS and remote sensing techniques. Esri International user conference.

Periyasamy, Punitha, Mahalingam Sudalaimuthu, Sachikanta Nanda, and Arasu Sundaram. 2014. Application of RS and GIS technique for identifying groundwater potential zone in Gomukhi Nadhi Sub Basin, South India. International Journal of Geological and Environmental Engineering 8 (12): 867-873.

Setiawan, Hery, Purnawali Teguh, Hariyanto Danar, Guruh Pratomo, and Nurin Hidayati. 2017. Flood vulnerability analysis using remote sensing and GIS: a case study of Sidoarjo regency. Surabaya: Abstracts of the 3rd international conference on civil engineering research.

Sumedh, R., Sandipan Das Warghat, Atul Doad, Sagar Mali, and Vishal S. Moon. 2012. Flood vulnerability analysis of the part of Karad region, Satara District, Maharashtra using remote sensing and geographic information system technique. International Journal of Advancements in Research \& Technology 1 (2): $1-7$.

\section{Submit your manuscript to a SpringerOpen ${ }^{\circ}$ journal and benefit from:}

- Convenient online submission

- Rigorous peer review

- Open access: articles freely available online

High visibility within the field

- Retaining the copyright to your article

Submit your next manuscript at $\boldsymbol{\sim}$ springeropen.com 